\title{
The Challenges, Opportunities and Performance of the Indian Pharmaceutical Industry Post-TRIPS
}

\author{
Biswajit Dhar and Reji K. Joseph
}

\begin{abstract}
India's generic pharmaceutical producers face numerous challenges after the country's patent law was amended to make it compatible with the Agreement on Trade-Related Aspects of Intellectual Property Rights (TRIPS). Two amendments were significant: introduction of product patent regime covering the area of pharmaceuticals, replacing the process patent regime existing earlier, and increase in patent term for pharmaceutical patents to 20 years, from the earlier 5-7 years (5 years from sealing of patent or 7 years from the date of application, whichever was lower). India's pre-TRIPS patent regime that did not allow product patents in the pharmaceutical sector provided the impetus for the emergence of a generic pharmaceutical industry from the 1980s.

How did the Indian pharmaceutical industry respond to the challenges posed by the TRIPS-consistent patent regime, in particular the product patent regime? This paper analysed a number of functional parameters to answer this question.

Analysis of the parameters explaining the size and the operational strengths of the major companies in the industry did not suggest structural weaknesses in the generic companies. They continued to remain the leaders in the industry, both in terms of invested capital and size of operations. They remained viable: their profit rates were higher than those in most major manufacturing sectors in India.

Although the major generic companies are all producers of generic medicines, they continued to invest sizeable shares of their sales turnover in research and development (R\&D). They have been active in taking patents, but their filings in foreign jurisdictions were significantly higher.
\end{abstract}

B. Dhar $(\triangle)$

Centre for Economic Studies and Planning,

School of Social Sciences, Jawaharlal Nehru University, New Delhi, India

R. K. Joseph

Institute for Studies in Industrial Development, New Delhi, India

e-mail: rejikjoseph@isid.org.in 


\section{Keywords}

TRIPS Agreement · Indian Patents Act of 1970 Generic pharmaceutical manufacturers $\cdot$ Patents $\cdot$ R\&D

\section{Introduction}

Since the 1980s, India has had a strong generic pharmaceutical industry that has been providing medicines at prices that are among the lowest in the world. The credit for the emergence of the generic industry should be given almost entirely to the Patents Act enacted in $1970^{1}$ that replaced the colonial Patents and Designs Act of $1911 .^{2}$ Two key provisions of Patents Act, 1970, were largely instrumental in supporting the growth of local entrepreneurship in the pharmaceutical industry. The first was discontinuation of the product patent regime covering all chemicals of the 1911 Act and introduction of a process patent regime. The second was the shortening of the period of patent protection for pharmaceutical processes to 5 years from grant or 7 years from the date of application, whichever was shorter, as against 14 years for all other fields of technology. The process patent regime allowed the Indian companies to develop alternative processes to produce generic versions of proprietary drugs. ${ }^{3}$

India's commitments to implement the Agreement on Trade-Related Aspects of Intellectual Property Rights (TRIPS) ${ }^{4}$ changed the favourable conditions enjoyed by the generic industry until then. The critical issue was the introduction of the product patent regime that restricted the ability of the generic companies to work around proprietary processes. The future prospects of these companies, therefore, hinged critically on the ability of the Indian policy makers to design a patent law that incorporated the flexibilities existing in the TRIPS Agreement.

Two substantial amendments ${ }^{5}$ were needed to make India's patent regime fully consistent with the TRIPS Agreement. The first was the amendment of the patentable subject matter by allowing patenting of microorganisms and "essentially non-biological processes" and increasing the term of patents to 20 years from the date of application. The second amendment introduced the product patent regime in

\footnotetext{
${ }^{1}$ The Patents Act 1970 (No. 39 of 1970), Gazette of India, 1970-09-21, Part II, Sec. 1.

${ }^{2}$ The Indian Patents and Design Act, 1911, Act 2 of 1911.

${ }^{3}$ Dhar and Rao (2002) discuss the case of the then leading firm in the pharmaceutical industry, Ranbaxy Laboratories.

${ }^{4}$ Agreement on Trade-Related Aspects of Intellectual Property Rights (Annex 1C to the Agreement establishing the World Trade Organization of April 15, 1994).

${ }^{5}$ Another amendment was introduced in 1999 to meet the requirements of Article 70.9 of the TRIPS Agreement. India was obligated to provide a so-called mailbox for receiving product patent applications from 1 January 1995, well ahead of the introduction of the product patent regime. In case patents were granted on any of these applications in a WTO member country, India had to provide "exclusive marketing rights" for 5 years or until the rights were granted or rejected in the country.
} 
the area of pharmaceuticals. The first two amendments had to be introduced on 1 January 2000, and the second was introduced on 1 January 2005.

This chapter analyses the performance of the pharmaceutical industry in India after the introduction of the TRIPS-compliant patent law. To set the context, the key elements of the TRIPS-compliant patent law are discussed in the first section. The second section discusses the performance of the Indian pharmaceutical industry since India began amending Patents Act, 1970, to make it TRIPS-compliant. This exercise uses various indicators to assess the viability of the leading pharmaceutical companies when TRIPS-compliant patent standards are being implemented.

\section{India's TRIPS-Compliant Patent Law}

One of the distinguishing features of the post-TRIPS patent law in India is that it seeks to balance the interests of the patent holder with the imperatives of public interest ${ }^{6}$ through two sets of provisions. The first relates to the scope of patentability and the second the compulsory licencing system. ${ }^{7}$

\subsection{Section 3(d): Preventing Grant of Patents on Minor Modifications}

Indian patent law has an important provision to prevent the grant of patents on minor modifications of known substances. Section 3(d) does not allow grant of patents on "mere discovery of a new form of a known substance which does not result in the enhancement of the known efficacy of that substance or the mere discovery of any new property or new use for a known substance or of the mere use of a known process, machine or apparatus unless such known process results in a new product or following: employs at least one new reactant". An explanation provided to this section says the following: "salts, esters, ethers, polymorphs, metabolites, pure form, particle size, isomers, mixtures of isomers, complexes, combinations and other derivatives of known substance shall be considered to be the same substance, unless they differ significantly in properties with regard to efficacy". This exclusion is aimed at ensuring that a product can be considered for the grant of patent only when the applicant can prove that the claimed invention has "enhanced efficacy" over an existing product.

\footnotetext{
${ }^{6}$ This feature of the Indian patent law brings it close to the realisation of the objectives of the TRIPS Agreement stated in Article 7: "The protection and enforcement of intellectual property rights should [be] to the mutual advantage of producers and users of technological knowledge and in a manner conducive to social and economic welfare, and to a balance of rights and obligations".

${ }^{7}$ Pre- and post-grant oppositions are the other important provisions that have been exploited in public interest.

${ }^{8}$ This was a point made by the Supreme Court when it heard Novartis' appeal against the rejection of its patent claim on an anticancer drug on the ground that it did not meet the standards of Section 3(d). Details are in the following discussion.
} 
Discussions in the Uruguay Round negotiations that led to the adoption of the TRIPS Agreement, provides the basis for Section 3(d), in our view. Participants dwelled on the problems arising from too short a period of patent protection to recoup the returns on investments in research and development (R\&D). ${ }^{9}$ They, therefore, argued that new norms and standards of intellectual property (IP) protection were needed, including longer period of patent protection. This, they opined, would sufficiently incentivise R\&D activities so that new molecules can be produced. ${ }^{10}$ These arguments were consistent with the persuasive position taken by Douglass North, who had argued that "development of a patent system and other laws protecting intellectual property ... encouraged the growth of innovation". ${ }^{11}$ This implies that longer term of patent protection can be justified only when innovators provide innovative products and processes, instead of minor modifications of known substances. In other words, it can be argued that providing 20-year patent protection for minor modifications of existing substances would tantamount to egregious rent seeking and would therefore be anti-competition and anti-innovation.

Yet another strong case in favour of Section 3(d) is that it is an effective bulwark against "evergreening" of patents. Some of the originator companies have made it a common practice to create minor variations to proprietary medicines and seek another "full" term of patent protection on the trivial modifications and to repeat this process for along as possible (hence, the name, "evergreening"). ${ }^{12}$ This strategy works well for these companies as they successfully block new entrants into the market even after the patent on the original medicine expires. This issue was highlighted by the Technical Committee (better known as the "Mashelkar Committee") that was appointed by the Indian Government to advice whether the Patents Act should limit the grant of a patent for pharmaceutical substance only to new chemical entities. The Mashelkar Committee recommended that the Patents Act must prevent "evergreening of patents", achieved by "executing trivial and insignificant changes to an already existing patented product". ${ }^{13}$

The legal validity of Section 3(d) was tested in the case that arose when Novartis petitioned against the rejection of the patent claim. The company had applied for a patent for the beta crystalline form of its anticancer drug, imatinib mesylate, in 1998. ${ }^{14}$ The application was rejected by the Indian Patent Office on three grounds, namely, that the claimed invention (i) was anticipated by prior publication, (ii) was obvious to a person skilled in the art judging from the disclosure provided in the

\footnotetext{
${ }^{9}$ GATT 1987, Submissions from Participants on Trade Problems Encountered in Connection with Intellectual Property Rights, p. 8.

${ }^{10}$ GATT 1988, Compilation of Written Submissions and Oral Statements - Prepared by the Secretariat: Revision, p. 15.

${ }^{11}$ North and Thomas $(1970,16)$.

${ }^{12}$ Ali and Rajagopal (2008).

${ }^{13}$ Report of the Technical Expert Group on Patent Law Issues 2006, paragraph 5.10.

${ }^{14}$ The product patent application followed the "mailbox" procedures that India had put in place on 1 January 1995.
} 
patent specifications and (iii) failed to meet the Section 3(d) standards. Novartis petitioned before High Court of Madras against the Patent Office ruling on its patent application. After the Intellectual Property Appellate Board (IPAB $)^{15}$ became functional in 2007, Novartis filed an appeal against the rejection of its application. When the IPAB rejected the patent claim, Novartis filed an appeal before the Supreme Court of India.

Novartis petitioned against the decision of the Patent Office in the High Court of Madras on two counts: (i) Section 3(d) of the Patents Act, 1970, was inconsistent with Articles 1(1) and 27 of the TRIPS Agreement and (ii) Section 3(d) was unconstitutional being vague, arbitrary and violative of Article 14 of the Constitution of India, which guarantees equality before law. ${ }^{16}$ The Court ruled that it did not have the jurisdiction to pass judgement on a provision of an international treaty and it therefore refused to comment on Novartis' contention that Section 3(d) violated, in particular, Article 27 of the TRIPS Agreement, which laid down the norms for patentable subject matter. However, the High Court made an important observation in the context of India's amendments to its Patents Act to make it compatible with the TRIPS Agreement. The Court argued that Article 7 of TRIPS Agreement "provides enough elbow room to a member country" to comply with its obligations under the Agreement "by bringing a law in a manner conducive to social and economic welfare and to a balance of rights and obligations" and added that Article 1 of the TIPS Agreement "enables a member country free to determine the appropriate method of implementing the provisions of this agreement within their own legal system and practice".

As regards the contention of the petitioner that Section 3(d) was unconstitutional as it was vague and arbitrary, and that it violated Article 14 of India's Constitution, the High Court observed that the legislature had clearly laid down the parameters the any patent applicant had to meet for obtaining a patent: "if a discovery is made from a known substance, a duty is cast upon the patent applicant to show that the discovery had resulted in the enhancement of a known efficacy of that substance and in deciding whether to grant a Patent or not on such new discovery". The Court ruled that Section 3(d) was not in violation of Article 14 of the Constitution of India. It was the Court's understanding that the Government of India had amended the Patents Act with the objective "to prevent evergreening; to provide easy access to the citizens of this country to life saving drugs and to discharge their Constitutional obligation of providing good health care to its citizens". ${ }^{17}$ Further, the debates in the Parliament on the third amendment of Patents Act showed that "welfare of the people of the country was in the mind of the Parliamentarians"18 and the Madras High Court, therefore, rejected Novartis' petition arguing that Section 3(d) violated Article 14 of the Constitution of India.

\footnotetext{
${ }^{15}$ IPAB was established by the Patents (Amendment) Act, 2002, which was the Second Amendment of the Patents Act in fulfilment of India's TRIPS commitments.

${ }^{16}$ Novartis AG v. Union of India, High Court of Madras, paragraph 2.

${ }^{17}$ Novartis AG v. Union of India, High Court of Madras, paragraph 19.

${ }^{18}$ Novartis AG v. Union of India, High Court of Madras, paragraph 15.
} 
Yet another interesting observation of the High Court was regarding the obligations that the TRIPS Agreement brought on the WTO member states: "Article 7 of [the TRIPS Agreement] provides enough elbow room to a member country in complying with [the] obligations by bringing a law in a manner conducive to social and economic welfare and to a balance of rights and obligations. Article 1 of [Agreement] enables a member country free to determine the appropriate method of implementing the provisions of this agreement within their own legal system and practice". ${ }^{19}$ Thus, the Court endorsed the interpretation that the TRIPS Agreement provided a number of flexibilities that the governments could creatively use to safeguard public interest.

Novartis filed an appeal against the ruling of the Patent Office after the IPAB was established in 2007. IPAB reversed the findings of the Patent Office that the beta crystalline form of imatinib mesylate did not stand the tests of novelty and nonobviousness. However, the Board rejected the appeal of Novartis against the Patent Office decision on the ground that the claimed invention had failed to meet the requirements of Section 3(d). The Board explanation of its decision was as follows: India has established "a requirement of higher standard of inventive step by introducing the amended section 3(d) of the Act, what is patentable in other countries will not be patentable in India. [T] he object of amended section 3(d) of the Act is nothing but a requirement of higher standard of inventive step in the law particularly for the drug/pharmaceutical substances". ${ }^{20}$

The Supreme Court of India heard the appeal of Novartis against the decision of the IPAB. The Court examined Novartis' petition in light of the criteria for inventive step laid down by India's Patents Act, in Article 2(1)(j) and 2(1)(ja). In particular, the Court asked if the product for which Novartis claimed patent protection qualified as a "new product" which was an invention that involved technical advance over existing knowledge and made the invention "not obvious" to "a person skilled in the art".

Upon its examination of Novartis' claims, especially on the use of Section 3(d) by the IPAB to reject its application for a patent for imatinib mesylate, the apex court made a critical observation regarding Section 3(d). This section, according to the Supreme Court of India, "clearly sets up a second tier of qualifying standards for chemical substances/pharmaceutical products in order to leave the door open for true and genuine inventions but, at the same time, to check any attempt at repetitive patenting or extension of the patent term on spurious grounds". ${ }^{21}$ The Supreme Court thus denied patent rights to Novartis for its anticancer drug, imatinib mesylate, since the claimed invention, in its view, did not meet the test of novelty and inventive steps besides failing to meet the requirements of Section 3(d).

\footnotetext{
${ }^{19}$ Novartis AG v. Union of India, High Court of Madras, 2007, paragraph 15.

${ }^{20}$ Novartis AG v. Union of India, The Supreme Court of India, 2013, paragraph 17.

${ }^{21}$ Novartis AG v. Union of India, The Supreme Court of India, 2013, paragraph 103.
} 


\subsection{Compulsory Licencing System}

Public interest considerations resulted in the adoption of the system of compulsory licensing (CL) in India. These provisions can be invoked where the patent monopolies are in conflict with public interest. India's Patents Act included the CL provisions, according to which, an application for the grant of CL can be made only after 3 years from the date of grant of the patent unless exceptional circumstances like national emergency or extreme urgency can be used to justify the grant of a licence on an earlier date. Three broad grounds for the grant of the CL have been spelt out in Section 84 of the Patents Act: (a) reasonable requirements of the public with respect to the patented invention have not been satisfied, (b) the patented invention is not available to the public at a reasonably affordable price and (c) the patented invention is not worked in the territory of India. However, a CL can be granted only when the patentee is paid adequate remuneration taking into account the economic value of the authorisation.

The provisions for the grant of CL are wholly consistent with the TRIPS Agreement as clarified in the Doha Declaration on TRIPS Agreement and Public Health. $^{22}$ In the Doha Declaration, adopted in 2001, Ministers of WTO Member States agreed that "TRIPS Agreement does not and should not prevent members from taking measures to protect public health". More importantly, Ministers agreed that the "Agreement can and should be interpreted and implemented in a manner supportive of WTO members' right to protect public health and, in particular, to promote access to medicines for all". And last, but not the least, the Declaration affirmed that "[E]ach Member has the right to grant compulsory licences and the freedom to determine the grounds upon which such licences are granted".

India has exercised a high degree of prudence in the use of CL provisions. In the post-TRIPS regime, there has been a solitary instance of the use of these provisions. This was done when Bayer Corporation, the American subsidiary of the German firm, Bayer AG, which held the patent on the anticancer drug sorafenib tosylate (sold under the brand name, Nexavar), charged unreasonably high price for the product and also did not make the drug available in sufficient quantities even through imports. The generic manufacturer Natco Pharma Ltd. applied for the grant of CL for domestically producing sorafenib tosylate, assuring that it could sell the medicine at Rs. 8000 (nearly \$130) for a month's supply, which was a fraction of Bayer Corporation's price of Rs. 2,80,000 (\$ 4600). Ruling on Natco Pharma's application, the Controller of Patents observed that Bayer was not making the patented invention available to the public at a reasonably affordable price and therefore granted a non-exclusive CL to the applicant. ${ }^{23}$ Natco Pharma Ltd. was required to pay Bayer Corporation royalty at the rate of $6 \%$ of the net sales of the medicine. ${ }^{24}$

\footnotetext{
${ }^{22}$ WTO (2001).

${ }^{23}$ Natco Pharma Ltd. vs Bayer Corporation: Application for Compulsory Licence Under Section 84(1) of the Patents Act, 1970 In Respect of Patent No.215758., Order issued on March 2012.

${ }^{24}$ Bayer Corporation challenged this ruling by the Controller of Patents in the Intellectual Property Appellate Board (IPAB). The IPAB upheld the ruling. Bayer Corporation challenged IPAB's deci-
} 
The above discussion shows the ways in which India used some of the available flexibilities in the TRIPS Agreement and has been able to provide a regime of patent protection in which the rights of the patent holder have been balanced with public interest imperatives. Importantly, the two crucial provisions that were discussed here have withstood scrutiny in its course of implementation and also upheld by the judiciary.

\section{$3 \quad$ Indian Pharmaceutical Industry Since the Implementation of TRIPS Agreement}

The previous section discussed the major amendments to Patents Act, 1970, to bring India's patent regime in conformity with the provisions of the Agreement on TRIPS, which included the introduction of the product patent regime. The generic companies that had thrived in the absence of a product patent regime, this amendment, therefore brought significant challenges. However, the Indian government fully utilised the flexibilities in the TRIPS Agreement and introduced several provisions so as to ensure that the generic industry could remain viable.

\subsection{Economic Performance of Leading Companies}

Did using flexibilities have the desired impact on the generic industry? This section will use a number of indicators to answer this question.

\subsubsection{Net Worth of 20 Largest Pharmaceutical Companies}

The first indicator that we shall use, one which provides evidence of the market value of the companies, is "net worth". Table 1 provides the details.

One of the distinctive features of the top 20 companies in the Indian pharmaceutical industry is that, measured in terms of the book value, domestic companies were ahead of the affiliates of foreign companies, like Pfizer and GlaxoSmithKline. In fact, this feature has been seen during the past three decades, i.e. ever since the generic companies were able to establish themselves in the industry. ${ }^{25}$

After the introduction of the post-TRIPS patent regime, the pharmaceutical industry in India displayed two-paced growth. During the previous decade, net worth of all the large domestic generic companies registered very high rates of growth. However, in the current decade, there has been a perceptible growth slowdown, not only of the industry but also of some of the companies like Dr. Reddy's and Cipla that have driven the consolidation and growth of the Indian industry since the 1990s. In recent years, Sun Pharmaceutical and Lupin have emerged as two of

sion before the Bombay High Court (Bayer Corporation vs Union of India, Writ Petition No. 1323 of 2013). The High Court once again rejected Bayer Corporation's contention against the grant of CL to Natco Pharma Ltd.

${ }^{25}$ Dhar and Rao 2002, Transfer of Technology for Successful Integration into the Global Economy: A case study of the Pharmaceutical Industry in India, p. 18. 
Table 1 Net worth of 20 largest pharmaceutical companies

\begin{tabular}{|c|c|c|c|c|}
\hline \multirow[b]{2}{*}{ Company name } & \multirow{2}{*}{$\begin{array}{l}\text { Net worth in } \\
\text { 2016-17 (US \$ } \\
\text { mn) }\end{array}$} & \multicolumn{3}{|c|}{ Average annual growth rate (AAGR, \%) } \\
\hline & & \begin{tabular}{|l} 
1999-2000 to \\
$2004-2005$
\end{tabular} & $\begin{array}{l}2005-2006 \text { to } \\
2010-2011\end{array}$ & $\begin{array}{l}\text { 2011-2012 to } \\
\text { 2016-2017 }\end{array}$ \\
\hline $\begin{array}{l}\text { Sun Pharmaceutical } \\
\text { Industries Ltd. }\end{array}$ & 3165.7 & 28.8 & 33.6 & 32.6 \\
\hline Lupin Ltd. & 2242.0 & 79.5 & 37.1 & 24.8 \\
\hline Cipla Ltd. & 1941.7 & 22.8 & 25.2 & 5.4 \\
\hline $\begin{array}{l}\text { Dr. Reddy's Laboratories } \\
\text { Ltd. }\end{array}$ & 1759.6 & 45.6 & 21.8 & 5.8 \\
\hline $\begin{array}{l}\text { Glenmark Pharmaceuticals } \\
\text { Ltd. }\end{array}$ & 1431.4 & 20.6 & 44.9 & 29.0 \\
\hline Aurobindo Pharma Ltd. & 1281.7 & 28.5 & 19.6 & 21.2 \\
\hline Cadila Healthcare Ltd. & 999.3 & 10.9 & 21.9 & 14.8 \\
\hline Biocon Ltd. & 992.1 & 79.9 & 17.4 & 25.4 \\
\hline Divi’s Laboratories Ltd. & 820.5 & 32.2 & 35.7 & 13.9 \\
\hline $\begin{array}{l}\text { Torrent Pharmaceuticals } \\
\text { Ltd. }\end{array}$ & 675.6 & 11.6 & 21.1 & 21.2 \\
\hline Alkem Laboratories Ltd. & 666.3 & 40.8 & 20.3 & 12.2 \\
\hline Strides Shasun Ltd. & 490.3 & 17.2 & 40.3 & 19.1 \\
\hline Ipca Laboratories Ltd. & 375.5 & 17.3 & 21.6 & 8.6 \\
\hline Pfizer Ltd. ${ }^{\mathrm{a}}$ & 366.9 & 21.4 & 25.8 & 32.7 \\
\hline $\begin{array}{l}\text { GlaxoSmithKline } \\
\text { Pharmaceuticals Ltd. }^{\text {a }}\end{array}$ & 307.7 & 17.9 & 11.2 & -3.0 \\
\hline Natco Pharma Ltd. & 257.2 & 26.0 & 19.9 & 23.2 \\
\hline Sanofi India Ltd. ${ }^{\mathrm{a}}$ & 255.6 & 26.3 & 12.0 & 4.1 \\
\hline Ajanta Pharma Ltd. & 228.1 & -3.1 & 14.8 & 33.6 \\
\hline $\begin{array}{l}\text { J B Chemicals and } \\
\text { Pharmaceuticals Ltd. }\end{array}$ & 210.5 & 16.6 & 17.5 & 2.5 \\
\hline Abbott India Ltd. ${ }^{\mathrm{a}}$ & 210.4 & 11.9 & 16.3 & 11.8 \\
\hline Average & & 28.5 & 24.3 & 17.2 \\
\hline
\end{tabular}

Source: Prowess Database provided by the Centre for Monitoring Indian Economy (CMIE), downloaded on 1 March 2018

Note: ${ }^{a}$ denotes affiliates of foreign companies in India

the largest leading companies in terms of their net worth. Although these companies grew much faster than the industry average, they were unable to balk the trend of slowing growth rates. Sun Pharmaceutical was able to increase its net worth nearly threefold since 2013-2014, largely due to its acquisition of Ranbaxy Laboratories, which was the undisputed leader of the Indian generic industry until the middle of the previous decade. Among the affiliates of foreign companies in the top 20 list, only Pfizer experienced steady growth in its net worth in the new millennium.

\subsubsection{Sales Turnover of Top 20 Pharmaceutical Companies}

The trends in the market presence of the largest generic pharmaceutical companies in India measured in terms of their sales turnover are similar to that of their net worth. After growing impressively in the previous decade, sales turnovers of most 
Table 2 Sales turnover of top 20 pharmaceutical companies

\begin{tabular}{|c|c|c|c|c|}
\hline \multirow[b]{2}{*}{ Companies } & \multirow[b]{2}{*}{$\begin{array}{l}\text { Sales in 2016- } \\
2017 \text { (US \$ mn) }\end{array}$} & \multicolumn{3}{|c|}{ Average annual growth in sales (\%) } \\
\hline & & $\begin{array}{l}1999-2000 \text { to } \\
2004-2005\end{array}$ & $\begin{array}{l}2005-2006 \text { to } \\
2010-2011\end{array}$ & $\begin{array}{l}\text { 2011-2012 to } \\
\text { 2016-2017 }\end{array}$ \\
\hline Lupin Ltd. & 1933.7 & 23.5 & 20.1 & 12.6 \\
\hline Cipla Ltd. & 1665.0 & 25.9 & 13.0 & 3.6 \\
\hline Aurobindo Pharma Ltd. & 1483.7 & 12.5 & 18.9 & 11.4 \\
\hline $\begin{array}{l}\text { Dr. Reddy's Laboratories } \\
\text { Ltd. }\end{array}$ & 1474.4 & 31.0 & 22.6 & 2.1 \\
\hline $\begin{array}{l}\text { Glenmark Pharmaceuticals } \\
\text { Ltd. }\end{array}$ & 1228.0 & 27.3 & 23.5 & 35.2 \\
\hline $\begin{array}{l}\text { Sun Pharmaceutical } \\
\text { Industries Ltd. }\end{array}$ & 1175.7 & 18.7 & 11.3 & 31.7 \\
\hline Alkem Laboratories Ltd. & 706.0 & -5.0 & 15.4 & 12.2 \\
\hline $\begin{array}{l}\text { Torrent Pharmaceuticals } \\
\text { Ltd. }\end{array}$ & 691.9 & 10.7 & 17.2 & 12.6 \\
\hline Divi's Laboratories Ltd. & 616.9 & 16.1 & 31.8 & 10.9 \\
\hline Cadila Healthcare Ltd. & 494.6 & 22.1 & 11.7 & 3.5 \\
\hline Ipca Laboratories Ltd. & 481.2 & 14.3 & 17.8 & 0.9 \\
\hline $\begin{array}{l}\text { GlaxoSmithKline } \\
\text { Pharmaceuticals Ltd. }\end{array}$ & 452.8 & 9.5 & 5.8 & 1.0 \\
\hline Abbott India Ltd. ${ }^{a}$ & 443.9 & 5.5 & 19.5 & 9.6 \\
\hline Biocon Ltd. & 398.8 & 40.2 & 14.1 & 4.9 \\
\hline Sanofi India Ltd. ${ }^{a}$ & 356.4 & 9.4 & 5.2 & 7.3 \\
\hline Wockhardt Ltd. & 348.5 & 2.9 & 15.3 & -3.7 \\
\hline Strides Shasun Ltd. & 321.0 & 13.1 & 14.8 & 25.9 \\
\hline Pfizer Ltd. ${ }^{a}$ & 310.7 & 15.2 & 5.9 & 11.7 \\
\hline Natco Pharma Ltd. & 306.2 & 14.9 & 15.8 & 32.0 \\
\hline Ajanta Pharma Ltd. & 276.5 & 11.9 & 18.0 & 18.0 \\
\hline Average & 1933.7 & 16.0 & 15.9 & 12.2 \\
\hline
\end{tabular}

Source: Same as Table 1

Note: ${ }^{\text {a }}$ denotes affiliates of foreign companies in India

companies in this decade were perceptively slower (Table 2). The two exceptions were Sun Pharmaceutical and Glenmark Pharmaceuticals; the sales turnovers of the two companies not only registering the fastest expansions in the industry, their growth rates in the current decade were the highest since the turn of the millennium.

The growth in sales registered by the leading generic producers in the early 1990s led to a complete transformation of the composition of market leaders in the Indian pharmaceutical industry. In 1994-1995, five of the ten top companies in terms of sales were the associates of foreign companies, with GlaxoSmithKline Pharmaceuticals Ltd. (then Glaxo India Ltd.) as the market leader. But two decades later, nine of the top ten sellers were generic companies. 
Over the past two decades, therefore, there has been an interesting transformation in the composition of top five companies in terms of sales turnover. In 19941995, the top five companies in terms of sales turnover included three affiliates of foreign companies (GlaxoSmithKline, Novartis and Aventis) and two generic companies (Ranbaxy and Cipla). By 2005-2006 this group included four generic companies (Ranbaxy, Dr. Reddy's, Cipla and Lupin) and one foreign affiliate (GlaxoSmithKline) with Ranbaxy at the top. In the current decade, only generic companies have figured in this group, with Cipla establishing itself as the market leader in most years. Cipla was the first company in the Indian industry to cross the threshold of 1-billion-dollar sales turnover in 2007-2008; by 2016-2017, five more companies figured in the billion-dollar league.

One aspect of the operations of the companies listed in Table 2 that has not been not captured is the growing importance of their global operations. For example, in 2016-2017, Sun Pharmaceutical Industries reported that foreign sales accounted for $68 \%$ of its revenue. ${ }^{26}$ Dr. Reddy's Laboratories, too, showed a similar tendency; foreign sales were $58 \%$ of the company's total revenue. ${ }^{27}$

Thus, the top 20 companies in the Indian pharmaceutical industry continued to expand their presence, both in the domestic and international markets, notwithstanding the uncertainties they faced following the introduction of the TRIPScompliant patent regime.

\subsubsection{Profitability Ratios of Top 20 Pharmaceutical Companies}

Pharmaceutical companies having the highest profitability ratios (or, profit to sales ratios) in the current decade are shown in Table 3. Except two exceptions, all companies included in the above table showed double-digit profit to sales ratios since 2011. But these figures were significantly lower than the ratios in the second half of the previous decade.

The largest companies were not among those having high profitability ratios. One possible explanation for this is that global operations of these companies have not been included in the data presented in Table 3. Thus, Sun Pharmaceutical Industries Ltd., which does not even figure in the list of top 20 companies having high profitability ratios, reported net profits of 23\% in 2016-2017 when the company's foreign sales are also considered. ${ }^{28}$ This figure was above the average profitability ratio for the industry since 2011-2012.

A noteworthy feature of the pharmaceutical industry is that it is the industry with the highest profitability ratio among all the leading sectors of the Indian industry (Fig. 1). Interestingly, the profitability of the pharmaceutical industry increased almost consistently through the period. It needs to be mentioned here that the pharmaceutical industry had outperformed other sectors of the industry despite facing significant uncertainties arising from the changes in the patent regime.

\footnotetext{
${ }^{26}$ Sun Pharmaceutical Industries Ltd. 2017-2018, Annual Report, p. 12.

${ }^{27}$ Dr. Reddy's Laboratories Ltd. 2017, Annual Report, p. 43.

${ }^{28}$ Sun Pharmaceutical 2017, Sun Pharma reports Q4 and FY17 results.
} 
Table 3 Pharmaceutical companies having highest profitability ratios (\%)

\begin{tabular}{l|c|l|l}
\hline Companies & $1999-2000$ to & $2005-2006$ to & $\begin{array}{l}2011-2012 \\
20016\end{array}$ \\
\hline Strides Shasun Ltd. & 8.3 & 4.2 & 58.3 \\
\hline Divi's Laboratories Ltd. & 17.9 & 32.1 & 28.4 \\
\hline Cadila Healthcare Ltd. & 11.0 & 18.4 & 24.4 \\
\hline Lupin Ltd. & 7.4 & 15.9 & 22.8 \\
\hline Glenmark Pharmaceuticals & 10.9 & 19.3 & 22.0 \\
\hline Ltd. & & & \\
\hline Torrent Pharmaceuticals Ltd. & 11.3 & 14.5 & 22.0 \\
\hline Ajanta Pharma Ltd. & 5.6 & 7.2 & 21.5 \\
\hline Natco Pharma Ltd. & 0.4 & 15.4 & 19.5 \\
\hline Pfizer Ltd. & 8.6 & 23.3 & 18.2 \\
\hline F D C Ltd. & 17.4 & 17.5 & 17.6 \\
\hline Alkem Laboratories Ltd. & 13.0 & 16.4 & 17.5 \\
\hline Biocon Ltd. & 21.3 & 25.3 & 16.0 \\
\hline GlaxoSmithKline & 11.9 & 29.3 & 16.0 \\
Pharmaceuticals Ltd. & & & \\
\hline Dr. Reddy's Laboratories Ltd. & 17.0 & 16.6 & 15.5 \\
\hline Aurobindo Pharma Ltd. & 7.3 & 11.4 & 14.0 \\
\hline Cipla Ltd. & 15.9 & 16.9 & 13.4 \\
\hline Sanofi India Ltd. & 11.5 & 16.7 & 13.2 \\
\hline Wockhardt Ltd. & 16.4 & -6.6 & 11.9 \\
\hline Ipca Laboratories Ltd. & 9.0 & 11.4 & 9.4 \\
\hline Abbott India Ltd. & 17.3 & 9.2 & 9.1 \\
\hline Soure: Sane a Table & & &
\end{tabular}

Source: Same as Table 1



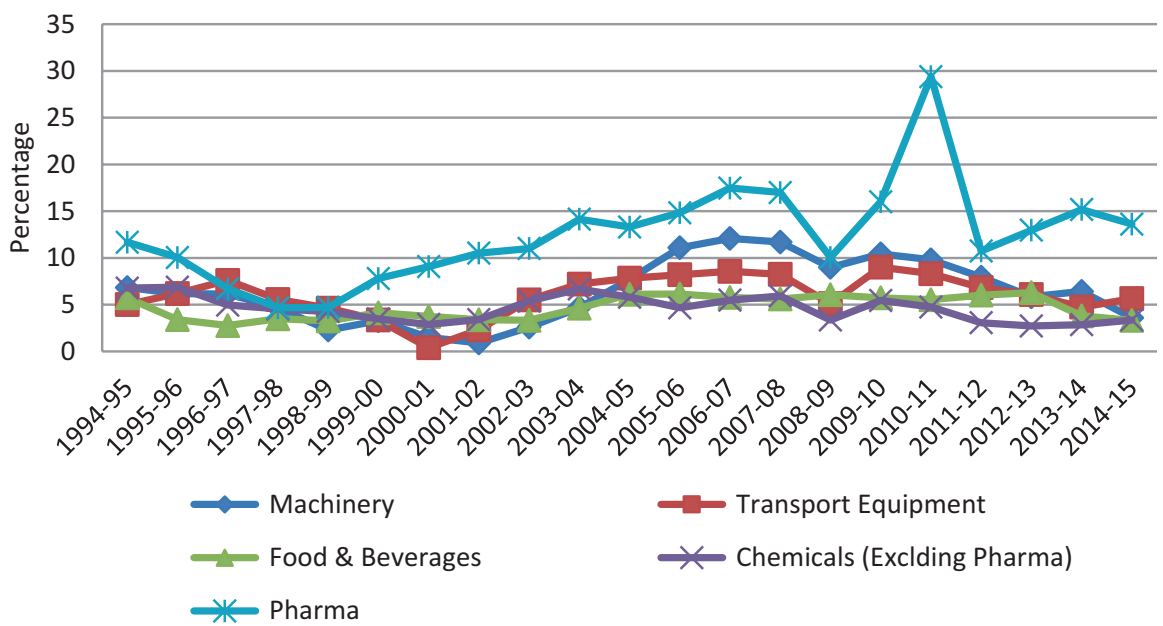

Source: Same as Table 1

Fig. 1 Profitability ratios in different industries in India. (Source: Same as Table 1) 


\subsection{Indian Industry in Global Markets}

We had mentioned in our earlier discussion that the generic pharmaceutical industry performed significantly better in the international markets. This was essentially because the leading companies of this industry were considerably more exportoriented as compared to those belonging to other industries. The trend towards enhancing the export-orientation of the industry had begun in the early 1990s, which went through a rapid consolidation in the subsequent years. This was particularly noticeable in case of the large generic firms in the industry. Table 4 shows that in recent years, foreign markets were substantially more important than the domestic market for several companies, including the large companies like Dr. Reddy's Laboratories and Cipla Ltd. Between 2011 and 2017, 74\% of the sales of Dr. Reddy's Laboratories were, on an average, in foreign markets, while for Cipla Ltd., the corresponding figure was nearly $51 \%$. It is also important to note that these companies have steadily increased their export orientation over time. Sun Pharmaceutical Industries did not report export figures in 2016-2017, which

Table 4 Top 20 companies with highest exports to total sales ratios (in \%)

\begin{tabular}{|c|c|c|c|}
\hline Company & $\begin{array}{l}1999-2000 \text { to } \\
2004-2005\end{array}$ & $\begin{array}{l}2005-2006 \text { to } \\
2010-2011\end{array}$ & $\begin{array}{l}2011-2012 \text { to } \\
2016-2017\end{array}$ \\
\hline Marksans Pharma Ltd. & 21.2 & 26.1 & 97.5 \\
\hline Hikal Ltd. & 79.6 & 78.5 & 77.5 \\
\hline Granules India Ltd. & 57.4 & 73.5 & 76.5 \\
\hline $\begin{array}{l}\text { Dr. Reddy's Laboratories } \\
\text { Ltd. }\end{array}$ & 53.0 & 63.1 & 73.9 \\
\hline Aurobindo Pharma Ltd. & 48.7 & 59.9 & 73.8 \\
\hline Neuland Laboratories Ltd. & 57.2 & 68.3 & 71.4 \\
\hline Kopran Ltd. & 26.3 & 53.7 & 70.2 \\
\hline Shilpa Medicare Ltd. & 53.3 & 73.3 & 64.8 \\
\hline Ind-Swift Laboratories Ltd. & 36.0 & 38.6 & 55.2 \\
\hline Cipla Ltd. & 35.9 & 50.6 & 50.7 \\
\hline Orchid Pharma Ltd. & 79.2 & 68.9 & 48.4 \\
\hline Biocon Ltd. & 48.3 & 44.1 & 46.4 \\
\hline Nectar Lifesciences Ltd. & 17.2 & 37.5 & 45.6 \\
\hline Wanbury Ltd. & 37.2 & 42.0 & 43.0 \\
\hline Indoco Remedies Ltd. & 6.1 & 24.2 & 35.0 \\
\hline Aarti Drugs Ltd. & 30.6 & 32.0 & 33.0 \\
\hline $\begin{array}{l}\text { Cadila Pharmaceuticals } \\
\text { Ltd. }\end{array}$ & 13.9 & 27.8 & 32.9 \\
\hline Panacea Biotech Ltd. & 8.5 & 26.5 & 32.9 \\
\hline Unichem Laboratories Ltd. & 8.9 & 19.2 & 31.7 \\
\hline Sanofi India Ltd. ${ }^{a}$ & 18.4 & 20.5 & 21.2 \\
\hline $\begin{array}{l}\text { Average for the top } 20 \\
\text { companies }\end{array}$ & 36.9 & 46.4 & 54.1 \\
\hline
\end{tabular}

Source: Same as Table 1

Note: ${ }^{a}$ denotes affiliate of foreign company in India 
explains its absence from Table 4, but in 2015-2016, 63\% of its sales were in foreign markets. The company met its international obligations through its subsidiaries located in other countries.

In contrast, affiliates of foreign companies operating in India do not engage significantly in exports; their production capacities in the country were increasingly being used for satisfying India's internal demand. This tendency stood out in case of the affiliates of some of the largest companies in the global industry like GlaxoSmithKline and Pfizer, which have reduced their exports from India since the middle of previous decade.

The strong performance of the generic industry in the global markets resulted from a number of its inherent advantages. It has been argued that Indian companies have lower costs - estimated to be one-eighth in R\&D activities and one-fifth in manufacturing - as compared to the Western companies. ${ }^{29}$ The cost advantages are most pronounced in respect of lower fixed asset costs and labour costs, where the costs in India can be one-eighth of the cost in the United States. Table 5 shows the trends in India's trade in pharmaceutical products.

Over the past two decades, India's total trade in pharmaceutical products increased from less than US\$ 2 billion to more than US \$27 billion. This expansion came on the back of a strong export performance, which, as the table above shows, increased from just over US\$ 1 billion dollars in 1996 to over US\$ 20 billion in 2016. Importantly, the pharmaceutical sector has been one of the few manufacturing sectors to have consistently increased its net foreign exchange earnings. Also, over the past 2 years, when India's exports have generally experienced uncertainties, the pharmaceutical industry was the only one among the manufacturing sector to have registered a healthy export growth (Table 6).

India's place in the global market as the supplier of cheap generics is confirmed by the pharmaceutical industry's growing presence in the market for formulations. Until the beginning of the current decade, exports of the active pharmaceutical ingredients (APIs) and the formulations were almost at par, but in the period since, exports of formulations have steadily increased, while exports of APIs have stagnated (Table 7).

Table 5 India's pharmaceutical trade - exports vs imports (in US \$ billions)

\begin{tabular}{l|l|l|l}
\hline Years & Exports & Imports & Trade balance \\
\hline 1996 & 1.2 & 0.7 & 0.6 \\
\hline 2000 & 1.9 & 0.8 & 1.1 \\
\hline 2005 & 5.2 & 2.1 & 3.1 \\
\hline 2010 & 11.4 & 5.5 & 5.9 \\
\hline 2012 & 16.6 & 7.3 & 9.3 \\
\hline 2014 & 18.4 & 7.8 & 10.6 \\
\hline
\end{tabular}

Source: Authors' estimates using UN Comtrade database

${ }^{29}$ Grace, Cheri (2004), The Effect of Changing Intellectual Property on Pharmaceutical Industry Prospects in India and China: Considerations for Access to Medicines, p. 8. 
Table 6 India's trade in pharmaceutical products by main categories (Figs. in US \$billions)

\begin{tabular}{l|l|l|l|l|l|l}
\hline \multirow{2}{*}{ Years } & \multicolumn{3}{l}{ Active pharmaceutical ingredients } & \multicolumn{2}{l}{ Formulations } \\
\cline { 2 - 7 } & Exports & Imports & Trade balance & Exports & Imports & Trade balance \\
\hline 1996 & 0.6 & 0.6 & 0.0 & 0.7 & 0.1 & 0.6 \\
\hline 2000 & 1.0 & 0.6 & 0.4 & 0.9 & 0.2 & 0.7 \\
\hline 2005 & 2.8 & 1.6 & 1.2 & 2.4 & 0.5 & 1.9 \\
\hline 2010 & 5.2 & 3.9 & 1.3 & 6.2 & 1.5 & 4.7 \\
\hline 2012 & 6.9 & 5.2 & 1.8 & 9.7 & 2.1 & 7.5 \\
\hline 2014 & 6.7 & 5.8 & 0.8 & 11.7 & 2.0 & 9.7 \\
\hline 2016 & 6.9 & 5.2 & 1.7 & 13.2 & 2.2 & 11.0 \\
\hline
\end{tabular}

Source: Authors' estimates using UN Comtrade database

Table 7 Exports of generic formulations to major regions (\% of total in parenthesis)

\begin{tabular}{l|l|l|l|l|l}
\hline Years & Africa & Asia & EU27 $^{\mathrm{a}}$ & North America & South America \\
\hline 1996 & $0.1(15.1)$ & $0.2(26.1)$ & $0.2(23.3)$ & $0.1(8.9)$ & $0.02(2.3)$ \\
\hline 2000 & $0.2(21.6)$ & $0.3(30.0)$ & $0.1(15.4)$ & $0.1(7.6)$ & $0.04(4.6)$ \\
\hline 2005 & $0.5(20.3)$ & $0.6(24.4)$ & $0.4(17.9)$ & $0.3(12.8)$ & $0.1(5.2)$ \\
\hline 2010 & $1.5(24.5)$ & $1.1(17.1)$ & $1.0(15.6)$ & $1.7(28.2)$ & $0.2(3.7)$ \\
\hline 2012 & $2.2(22.7)$ & $1.6(16.6)$ & $1.4(14.3)$ & $3.2(32.8)$ & $0.4(3.7)$ \\
\hline 2014 & $2.9(24.5)$ & $1.9(16.3)$ & $1.5(13.1)$ & $4.0(33.9)$ & $0.5(4.4)$ \\
\hline 2016 & $2.9(22.0)$ & $2.1(15.8)$ & $1.6(12.0)$ & $5.4(40.6)$ & $0.4(3.2)$ \\
\hline
\end{tabular}

Source: Authors' estimates using UN Comtrade database

Note: ${ }^{\mathrm{E} U} \mathrm{E}-27$ in the UN Comtrade database is an economic grouping created for statistical purposes. The Statistical Office of the European Union (Eurostat) provides EU-27 data

In 1995-1996, more than one-half of the exports of formulations by Indian generic companies were destined to Europe and Asia. Two decades later, the share of these two regions declined to a quarter. This decline, however, was not because of the decline in the value of exports but rather the expansion of exports to other regions. Decline in the share of Europe and Asia was matched by the expansion of exports to North America and Africa. In 2016, North America was the single largest market for India's formulations, with a $41 \%$ share. Exports to this region grew from a mere $\$ 60$ million in 1996 to more than \$5 billion in 2016. Penetration of Indian generic companies in Africa was also particularly noticeable. Between 2003 and 2016, exports of Indian formulations to Africa increased nearly tenfold, from $\$ 270$ million to almost \$3 billion.

The United States was the single largest market for Indian formulations with a $39 \%$ share. This market had expanded from less than \$300 million in 2005 to over $\$ 5.2$ billion in 2016. The relative importance of the European Union as a market for Indian generics had, however, fallen during the same period. The chart below provides a summary of the main destinations of Indian formulations (Chart 1).

India's place in the global market as a supplier of generic medicines is somewhat diminished by the fact that it is now a major importer of APIs. Between 2005 and 2016, API imports have increased more than threefold. Exports of APIs have also expanded, almost doubling between 2005 and 2016. China has emerged as India's 


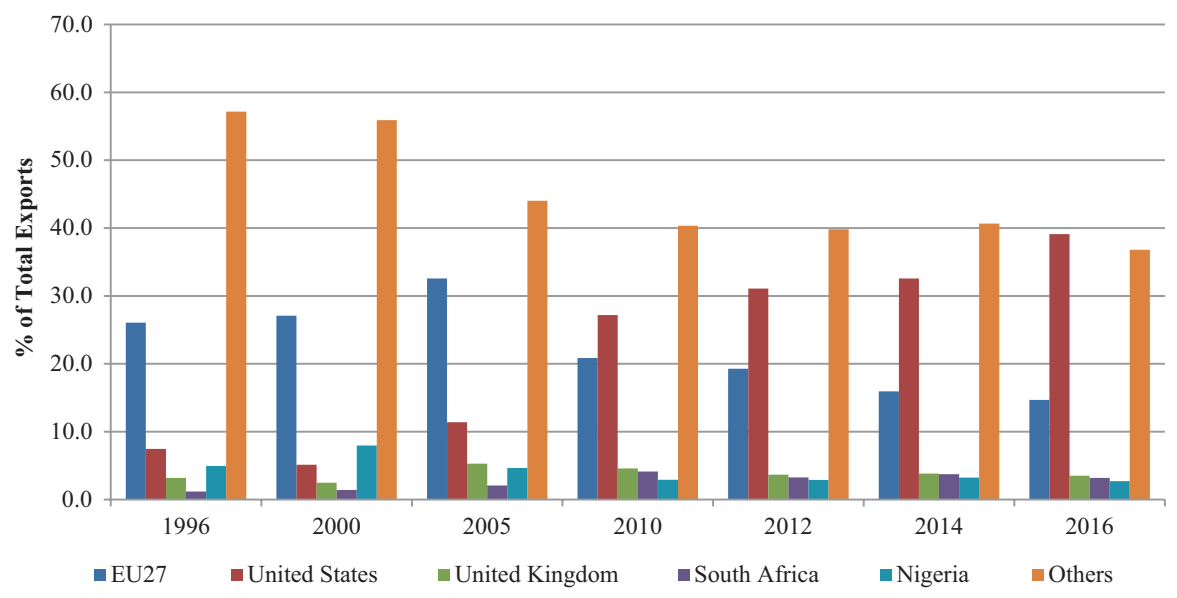

Source: Same as table 5

Chart 1 Major export destinations of Indian formulations. (Source: Same as Table 5)

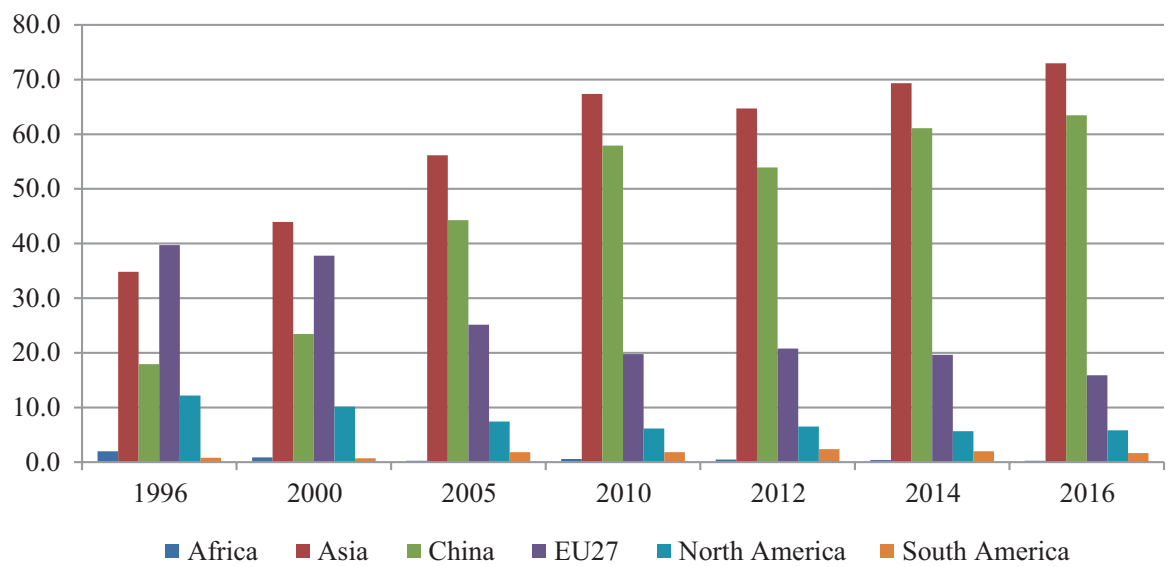

Chart 2 India: sources of imports of APIs

largest supplier of APIs, accounting for nearly two-thirds of its total imports from its northern neighbour (Chart 2).

\subsection{Penetration of Indian Generics into Industrially Advanced Countries: The Case of the United States}

Since the mid-1980s, Indian generic manufacturers benefited from a series of changes in the regulatory framework adopted by the US Food and Drug Administration (FDA), which explicitly favoured the generic drugs. The most 
significant of these was the Drug Price Competition and Patent Restoration Act of 1984 (better known as "the Hatch-Waxman Act") that created opportunities for marketing of generics or the so-called abbreviated new drug applications (ANDAs). The Hatch-Waxman Act established the ANDA approval process, which allows lowerpriced generic versions of previously approved innovator drugs to be brought into the market. The Hatch-Waxman Act established bioequivalence as the basis for approving generic copies of drug products. This allows the FDA to grant approvals to market generic versions of proprietary drugs without going through the costly and duplicative clinical trials for establishing the safety and efficacy of the generics.

An ANDA contains data which is submitted to FDA for the review and potential approval of a generic drug product. Once approved, an applicant may manufacture and market the generic drug to provide a safe, effective, lower-cost alternative to the brand-name drug. All approved products, both innovator and generic, are listed in FDA's Approved Drug Products with Therapeutic Equivalence Evaluations (Orange Book).

Generic drug applications are termed "abbreviated" because they are generally not required to include preclinical (animal) and clinical (human) data to establish safety and effectiveness. Instead, generic applicants must scientifically demonstrate that their product performs in the same manner as the innovator drug. One-way applicants demonstrate that a generic product performs in the same way as the innovator drug is the time it takes the generic drug to reach the bloodstream in healthy volunteers. This demonstration of "bioequivalence" gives the rate of absorption, or bioavailability, of the generic drug, which can then be compared to that of the innovator drug. To be approved by FDA, the generic version must deliver the same amount of active ingredients into a patient's bloodstream in the same amount of time as the innovator drug.

Market penetration of generic drugs increased rapidly after the enactment of Hatch-Waxman Act. By the early years of the new millennium, generic drugs comprised of more than $47 \%$ of the prescriptions filled for pharmaceutical products, up from $19 \%$, when the Act came on the statute book..$^{30}$ Generic drugs continued to gain in popularity in the United States; the Office of Generic Drugs of the FDA reports that currently, 9 out of 10 prescriptions filled are for generic drugs. ${ }^{31}$ Increasing the availability of generic drugs helps to create competition in the marketplace, which then helps to make treatment more affordable and increases access to healthcare for more patients. One estimate shows that due to the availability of low-cost generics, the healthcare system in the United States was able to save $\$ 263$ billion in 2016 and nearly $\$ 1.7$ trillion over the past decade. ${ }^{32}$

\footnotetext{
${ }^{30}$ US Federal Trade Commission, Competition and Intellectual Property Law and Policy in the Knowledge-Based Economy 2002, p. i.

${ }^{31}$ US Food and Drug Administration, Orange Book: Preface (online publication).

${ }^{32}$ Association for Accessible Medicines, Generic Drug Access and Savings in the United States, report prepared by the IMS Health Institute 2017, 20.
} 
The market penetration made by the Indian generic companies can be seen from the approvals they have been receiving from the FDA for the marketing products on the basis of their safety and efficacy. The approvals published in the "Orange Book" have been based on clearly defined criteria. ${ }^{33}$

Table 8 and Chart 3 show that until the late 1990s, Indian generic manufacturers received very few approvals from FDA to market their products in the United States. Although this trend had changed from early 2000s, it was only after the middle of the previous decade that there was quantum leap in the number of approvals received by Indian companies. Sun Pharmaceutical and Aurobindo Pharma Ltd., along with their group companies, were the main beneficiaries. A notable feature of the marketing approvals obtained was that the Indian generics have a major share of prescription drugs.

\subsection{The Technology Dimension}

The pharmaceutical industry can be divided into three product groupings, viz. bulk drugs, intermediates and formulations. While bulk drug production can be sustained over a long period only through sustained involvement in R\&D activities, formulation production can be carried out with relatively low levels of technological sophistication.

During the past decade, however, the R\&D profile of the Indian pharmaceutical industry has undergone major changes. The most obvious of these is the manifold increase in the spending on $R \& D$, particularly since the beginning of the current decade. The increase in $R \& D$ intensity ( $R \& D$ to sales) of the Indian pharmaceutical industry since 1999-2000 is the other significant aspect. This is an indication that the pharmaceutical industry in India is allocating increasing amounts of its sales turnover towards R\&D spending (Chart 4).

Until the end of 1990s, the pharmaceutical industry, like other major industries, was spending only less than $1.5 \%$ of sales on R\&D. But from the beginning of current decade, there is a steep increase in the R\&D spending, from 2\% in 2000-2001 to nearly $7 \%$ in 2015-2016. This trend is strongly reinforced by the R\&D-intensive companies in industry (Table 9).

The top 20 companies in terms of R\&D intensities were all manufacturers of generic medicines. Major companies, including Sun Pharmaceutical Industries, Dr.

\footnotetext{
${ }^{33} \mathrm{FDA}$ classifies as therapeutically equivalent those products that meet the following general criteria: (1) they are approved as safe and effective; (2) they are pharmaceutical equivalents in that they (a) contain identical amounts of the same active drug ingredient in the same dosage form and route of administration and (b) meet compendia or other applicable standards of strength, quality, purity and identity; (3) they are bioequivalent in that (a) they do not present a known or potential bioequivalence problem, and they meet an acceptable in vitro standard, or (b) if they do present such a known or potential problem, they are shown to meet an appropriate bioequivalence standard; (4) they are adequately labelled; and (5) they are manufactured in compliance with current Good Manufacturing Practice regulations (for details, see US FDA. Orange Book: Preface, 2018).
} 


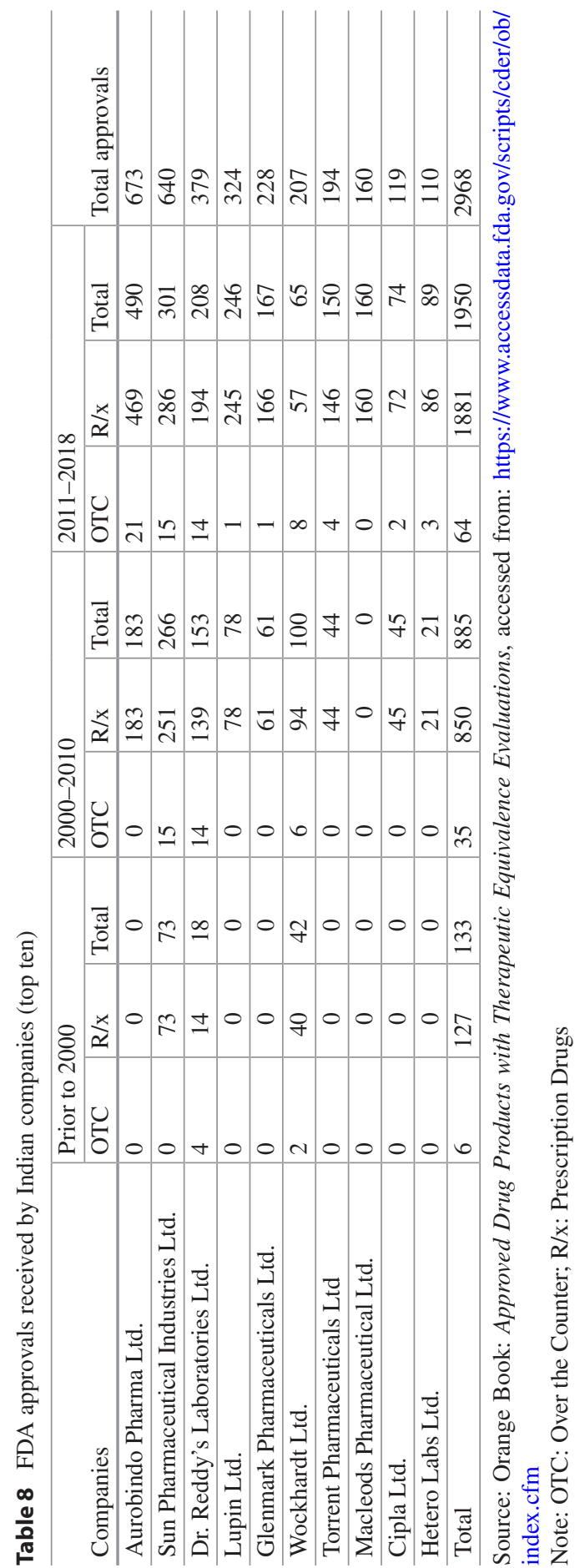




\section{Number of Annual Approvals}

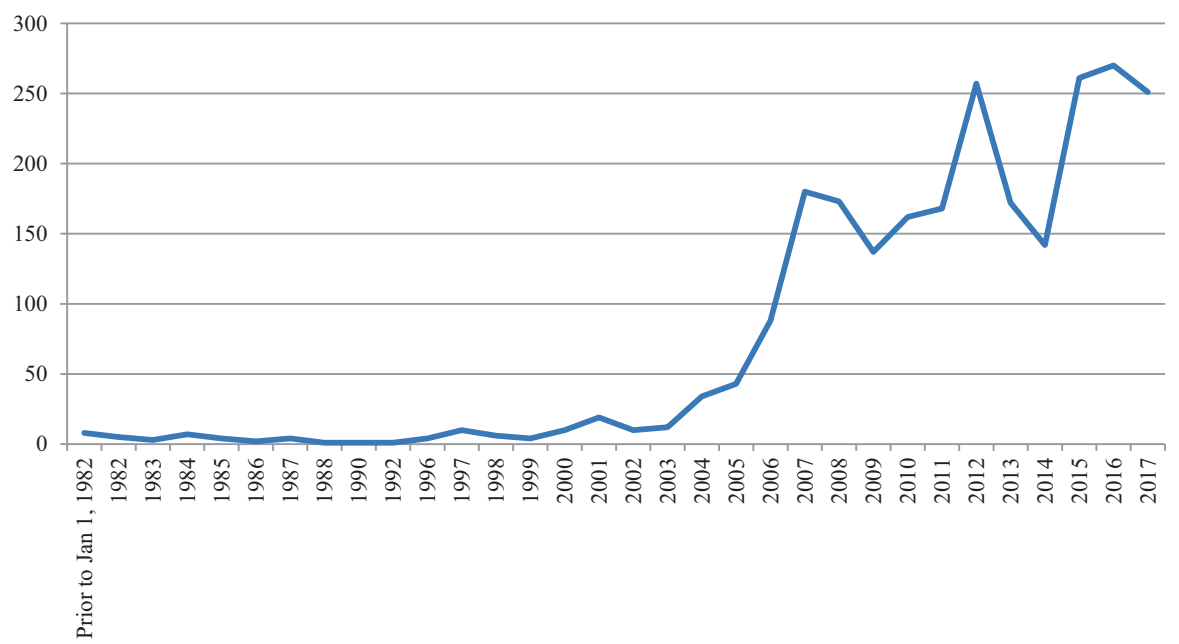

Chart 3 Trends in FDA approvals received by Indian companies (top ten recipients). (Source: Orange Book, accessed from: https://www.accessdata.fda.gov/scripts/cder/ob/index.cfm)

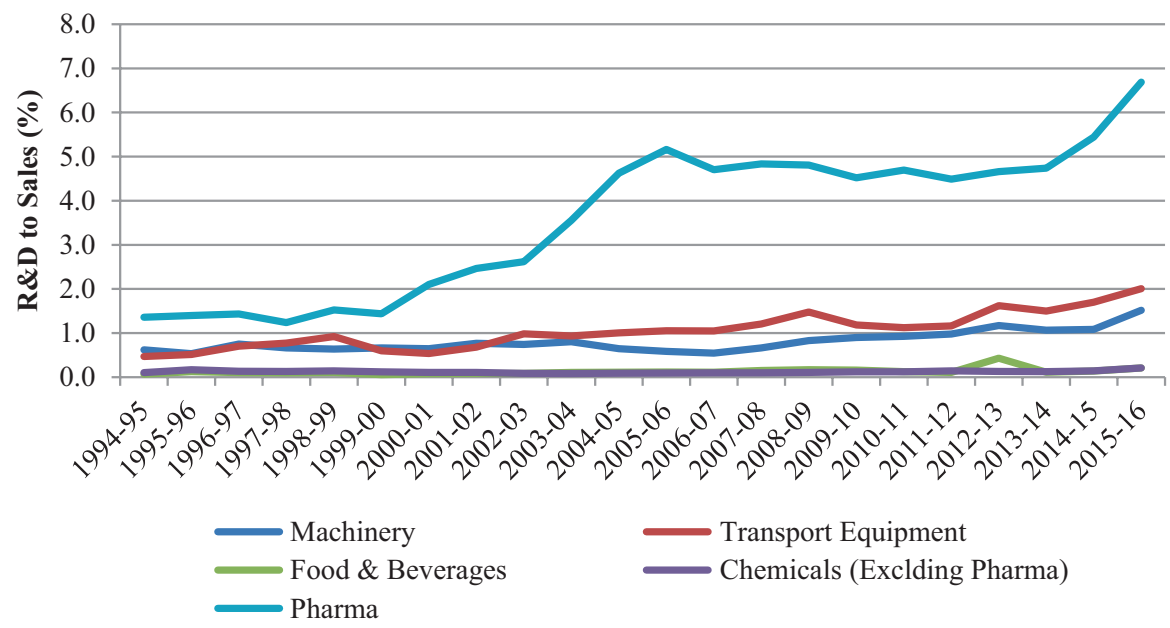

Source: Same as table 1

Chart 4 Ratio of R\&D to sales of major sectors in India. (Source: Same as Table 1)

Reddy's Laboratories, Cipla and Lupin Laboratories, registered upward trends in their R\&D intensities from the beginning of the 2000s.

Globally, pharmaceutical industry is an R\&D-intensive industry, with several large companies spending upwards 15\% of their sales on research (Table 10). 
Table 9 R\&D intensities of top 20 pharmaceutical companies (Figs. in \%)

\begin{tabular}{|c|c|c|c|}
\hline Companies & $\begin{array}{l}\text { 1999-2000 to } \\
2004-2005\end{array}$ & \begin{tabular}{|l}
$2005-2006$ to \\
$2010-2011$
\end{tabular} & $\begin{array}{l}2011-2012 \text { to } \\
2016-2017\end{array}$ \\
\hline Panacea Biotec Ltd. & 3.0 & 6.1 & 13.7 \\
\hline Lupin Ltd. & 3.6 & 8.0 & 12.7 \\
\hline Cadila Healthcare Ltd. & 4.0 & 8.7 & 12.5 \\
\hline Suven Life Sciences Ltd. & 6.8 & 19.9 & 11.9 \\
\hline $\begin{array}{l}\text { Dr. Reddy's Laboratories } \\
\text { Ltd. }\end{array}$ & 9.1 & 9.1 & 10.9 \\
\hline $\begin{array}{l}\text { Sun Pharmaceutical } \\
\text { Industries Ltd. }\end{array}$ & 2.8 & 6.8 & 10.3 \\
\hline Wockhardt Ltd. & 5.2 & 3.0 & 8.8 \\
\hline Ind-Swift Laboratories Ltd. & 1.8 & 8.3 & 6.9 \\
\hline Ajanta Pharma Ltd. & 0.6 & 3.5 & 6.1 \\
\hline Cipla Ltd. & 3.1 & 4.3 & 6.1 \\
\hline $\begin{array}{l}\text { Glenmark Pharmaceuticals } \\
\text { Ltd. }\end{array}$ & 4.5 & 4.6 & 5.6 \\
\hline $\begin{array}{l}\text { Torrent Pharmaceuticals } \\
\text { Ltd. }\end{array}$ & 6.4 & 8.9 & 5.4 \\
\hline Natco Pharma Ltd. & 0.8 & 2.8 & 5.3 \\
\hline Biocon Ltd. & 2.4 & 5.3 & 4.9 \\
\hline Unichem Laboratories Ltd. & 1.8 & 3.9 & 4.5 \\
\hline Aurobindo Pharma Ltd. & 1.2 & 3.6 & 4.1 \\
\hline Orchid Pharma Ltd. & 1.7 & 3.4 & 3.8 \\
\hline Ipca Laboratories Ltd. & 1.9 & 3.0 & 3.7 \\
\hline Indoco Remedies Ltd. & 0.8 & 2.0 & 3.1 \\
\hline Divi's Laboratories Ltd. & 1.8 & 1.2 & 1.0 \\
\hline Average & 3.2 & 5.8 & 7.1 \\
\hline
\end{tabular}

Source: CMIE, Prowess database

Tables 9 and 10 show that in 2017, Indian generics were lagging behind the research-intensive global companies. But, as mentioned above, the encouraging fact for the Indian pharmaceutical companies is that a number of companies have graduated into the league of companies that have double-digit R\&D intensities.

A quick check on the R\&D output of some of the leading companies can be made through their patenting activity. Table 11 shows that there is a correspondence between the worldwide patent filings of the companies and their R\&D spending. However, while Dr. Reddy's and Lupin Laboratories had either remained range bound or had increased their patent filings between 2010 and 2017, Cipla had decreased their patenting activity during this period.

Table 12 provides the data on the patents granted to a few major Indian companies in India, after the introduction of the product patent regime. Immediately after the introduction of the product patent regime in pharmaceuticals, the leading Indian companies obtained a significant number of patents in India. However, in the current decade, these companies were unable to maintain the momentum. 
Table 10 R\&D intensity of top ten companies in pharmaceuticals and biotechnology sectors (2017)

\begin{tabular}{l|l}
\hline Company & $\begin{array}{l}\text { R\&D } \\
\text { intensity (\%) }\end{array}$ \\
\hline Johnson \& Johnson & 12.7 \\
\hline Novartis & 18.2 \\
\hline Bayer & 10.0 \\
\hline Pfizer & 14.7 \\
\hline Roche & 19.6 \\
\hline Merck US & 17.2 \\
\hline Sanofi & 14.1 \\
\hline GlaxoSmithKline Pharmaceuticals & 12.1 \\
\hline Ltd & \\
\hline AstraZeneca & 24.6 \\
\hline Gilead Sciences & 15.4 \\
\hline Average & 15.9
\end{tabular}

Source: The 2017 EU Industrial R\&D Investment Scoreboard (accessed from: http://iri.jrc.ec.europa.eu/ scoreboard17.html)

Table 11 Worldwide patent filings by major Indian companies by year of publication

\begin{tabular}{l|l|l|l|l|l}
\hline Years & Dr. Reddy's & Lupin & Cipla & Natco Pharma & Sun Pharmaceutical \\
\hline 2000 & 10 & 7 & 5 & 0 & 0 \\
\hline 2005 & 54 & 35 & 61 & 15 & 5 \\
\hline 2010 & 75 & 40 & 68 & 13 & 5 \\
\hline 2015 & 53 & 76 & 71 & 14 & 4 \\
\hline 2017 & 65 & 74 & 44 & 17 & 1 \\
\hline
\end{tabular}

Source: Espacenet Patent search, https://worldwide.espacenet.com

Table 12 Patents granted to Indian generic companies in India

\begin{tabular}{l|l|l}
\hline \multirow{2}{*}{ Companies } & \multicolumn{2}{|l}{ Patents granted } \\
\cline { 2 - 3 } & $2005-2009$ & $\begin{array}{l}2010- \\
2013\end{array}$ \\
\hline Cipla Ltd. & 19 & 4 \\
\hline Dr. Reddy's Laboratories & 22 & 0 \\
\hline Lupin Ltd. & 6 & 0 \\
\hline Natco Pharma & 16 & 0 \\
\hline Panacea Biotech Ltd. & 8 & 7 \\
\hline $\begin{array}{l}\text { Sun Pharmaceutical Industries } \\
\text { Ltd. }\end{array}$ & 8 & 1 \\
\hline Souce: Controler Gena & & \\
\hline
\end{tabular}

Source: Controller General of Patents, Designs and Trade Marks, India

Another interesting fact is the patenting activities of the leading generic companies in India and in other jurisdictions were significantly different. While companies like Lupin Laboratories and Natco had increased their worldwide patent filings, they had stopped filing for patents in the Indian Patent Office. This behaviour needs to be analysed looking at their firm-level characteristics, which is beyond the scope of this chapter. 


\section{$4 \quad$ Concluding Remarks}

The strong presence of companies producing generic medicines has given a special character to the Indian pharmaceutical industry. The growth of these companies and their subsequent consolidation can largely be attributed to the Patents Act enacted in 1970. This legislation had two key features that provided space for the growth of the generic companies. First, the Patent Law, 1970, allowed grant of only process patents for chemicals, including pharmaceuticals, and second, the term of patent protection was shorter for pharmaceutical patents. The process patent regime, in particular, enabled the generic manufacturers to develop alternative processes for proprietary products that were already in the market.

India's accession to the TRIPS Agreement led to fundamental changes in the country's patent regime. The two key provisions of Patents Act, 1970, which the generic companies had benefited from, were amended. Product patents were introduced to cover pharmaceutical innovations, and a uniform period of patent protection of 20 years was introduced.

However, the Government of India exploited the flexibilities of the TRIPS Agreement and introduced two provisions in the amended Patents Act that could lessen the impact on the generic companies. The first was Section 3(d) that does not allow patents on minor modifications of existing product. This objective of this provision was to eliminate the possibilities of "evergreening of patents". Section 3(d) ensures that public domain allows the generic companies to continue operating in the industry.

The second provision provided by the Indian Patents Act is the possibility for the grant of compulsory licencing if the patent is not worked in India or the product resulting from the exploitation of the patent has exorbitant prices. Importantly, both these flexibilities have successfully stood scrutiny, including by the highest court of the land.

This study analysed the performance of the Indian pharmaceutical industry in the post-TRIPS patent regime. Our analysis showed that the leading generic companies of the industry have mixed performance. While most indicators exhibited an upward trend through the previous decade, in the present decade, there has been some slowing of the growth rates. These figures do not provide conclusive evidence about the health of the industry.

The industry as a whole and some of the leading companies in particular have shown considerable improvement in R\&D intensity since the previous decade. An indicator of the better performance of the industry has been the increase in its patenting activity, as reflected in the figures of the major companies.

For the past two decades, the Indian pharmaceutical industry has emerged a global player, by being a supplier of affordable medicines to a large number of countries. Some of the leading companies, including the largest company, namely, Sun Pharmaceutical Industries Ltd., have larger shares of their businesses in the global markets. The major markets of the industry are in the developed world, especially in the United States. In this market, the Indian pharmaceutical companies have been able to exploit the opportunities provided to the generic companies by the Hatch-Waxman Act of 1984, which provides an easier set of regulatory requirements for these companies to obtain marketing approval. 
In an ever-shifting world of intellectual property protection, the Indian pharmaceutical industry faces considerable challenges. The flexibilities provided by the Indian Patents Act, which has provided some space to the manufacturers of generic medicines in the country, have been critically commented on by two of India's largest economic partners, namely, the United States and the EU. The United States Trade Representative (USTR) has been conducting annual investigations under Special $301^{34}$ since 1989, and in each annual investigation, India has been named either as a "Priority Foreign Country" or has been included it in the "Priority Watch List". The former designation is for countries "that have the most onerous or egregious acts, policies, or practices and whose acts, policies, or practices have the greatest adverse impact (actual or potential) on the relevant US products" and the latter for countries in which "problems exist ... with respect to IP protection, enforcement, or market access for persons relying on [intellectual property]". ${ }^{35}$

In 2014, the European Commission adopted the "Strategy for the protection and enforcement of intellectual property rights in third countries" for "fighting IPR infringements in third countries..." ${ }^{36}$ As a part of this strategy, the Commission identified India as a country, which has "[r]estrictive patentability criteria combined with difficulties to enforce patents granted, as well as very broad criteria being applied for granting compulsory licenses or for revoking patents" that "make effective patent protection in India very difficult, notably for pharmaceuticals and chemicals ...". ${ }^{37}$

\section{References}

Agreement on Trade-Related Aspects of Intellectual Property Rights (Annex 1C to the Agreement establishing the World Trade Organization of April 15, 1994). Accessed from: https://www. wto.org/english/docs_e/legal_e/27-trips_01_e.htm

Ali, F., \& Rajagopal, S. (2008). Rampant evergreening in Indian pharma industry, Livemint, 28 April. Accessed from: https://www.livemint.com/Opinion/aIqAgfMWLyel1uPEfEcEtI/ Rampant-evergreening-in-Indian-pharma-industry.html

Association for Accessible Medicines. (2017). Generic drug access \& savings in the U.S., report prepared by the IMS Health Institute. Accessed from: https://accessiblemeds.org/sites/default/ files/2017-07/2017-AAM-Access-Savings-Report-2017-web2.pdf

Dhar, B., \& Rao, C. N. (2002). Transfer of Technology for Successful Integration into the global economy: A case study of the pharmaceutical industry in India. UNCTAD/UNDP Programme on Globalization, Liberalization and Sustainable Development, United Nations, Geneva.

Dr. Reddy's Laboratories Limited. (2017). Annual report 2016-17. Accessed from: https://www. drreddys.com/media/652025/annual-report-2017.pdf

European Commission. (2014). Trade, growth and intellectual property - Strategy for the protection and enforcement of intellectual property rights in third countries: Communication from the Commission to the European Parliament, the Council and the European Economic and Social

\footnotetext{
${ }^{34}$ These investigations are conducted under Section 182 of the Trade Act of 1974, as amended by the Omnibus Trade and Competitiveness Act of 1988, the Uruguay Round Agreements Act and the Trade Facilitation and Trade Enforcement Act of 2015 (19 U.S.C. § 2242).

${ }^{35}$ Office of the United States Trade Representative (2018), p. 8.

${ }^{36}$ European Commission (2014), p. 4.

${ }^{37}$ European Commission (2018), p. 13.
} 
Committee, COM(2014) 389 final. Accessed from: http://trade.ec.europa.eu/doclib/docs/2014/ july/tradoc_152643.pdf

European Commission. (2018). Report on the protection and enforcement of intellectual property rights in third countries, SWD(2018) 47 final, Accessed from: http://trade.ec.europa.eu/doclib/ docs/2018/march/tradoc_156634.pdf

Federal Trade Commission. (2002). Generic drug entry prior to patent expiration: An FTC study, Washington, DC, at http://www.ftc.gov/os/2002/07/genericdrugstudy.pdf

Federal Trade Commission/Department of Justice. (2002). Competition and intellectual property law and policy in the knowledge-based economy, Hearings, at: www.ftc.gov/os/comments/ intelpropertycomments/aventis.pdf

GATT. (1987). Submissions from participants on trade problems encountered in connection with intellectual property rights, MTN.GNG/NG11/W/7, 29 May.

GATT. (1988). Compilation of written submissions and oral statements - prepared by the secretariat: Revision, MTN.GNG/NG11/W/12/Rev.1., 5 February.

Grace, C. (2004). The effect of changing intellectual property on pharmaceutical industry prospects in India and China. London: DFID Health Systems Resources Centre.

North, D. C., \& Thomas, R. P. (1970, April). An economic theory of the growth of the western world. The Economic History Review, 23(1), 1-17.

Novartis AG v. Union of India, Writ Petition Nos.24759 and 24760 of 2006, High Court of Madras, 2007.

Novartis AG v. Union of India, Civil Appeal Nos. 2706-2716 OF 2013, The Supreme Court of India, 2013.

Office of the United States Trade Representative (2018). 2018 Special 301 report. Accessed from: https://ustr.gov/sites/default/files/files/Press/Reports/2018\%20Special\%20301.pdf

Report of the Technical Expert Group on Patent Law Issues. (2006). Accessed from: http:// www.ipindia.nic.in/writereaddata/images/pdf/report-of-technical-expert-group.pdf, on 10 September 2017.

Sun Pharmaceutical Industries Ltd. (2017). Sun Pharma reports Q4 \& FY17 results. Accessed from: www.sunpharma.com/sites/default/files/financialpdfs/Press\%20Release\%20Sun\%20Pharma\%20 Q4\%20FY17\%20Financial\%20Result.pdf

US Food and Drug Administration. (2018). Orange book: Preface. Accessed from: https://www. fda.gov/Drugs/DevelopmentApprovalProcess/ucm079068.htm, on 1 March 2018.

WTO. (2001). Declaration on the TRIPS agreement and public health: Adopted on 14 November 2001, WT/MIN(01)/DEC/2.

Open Access This chapter is licensed under the terms of the Creative Commons Attribution 4.0 International License (http://creativecommons.org/licenses/by/4.0/), which permits use, sharing, adaptation, distribution and reproduction in any medium or format, as long as you give appropriate credit to the original author(s) and the source, provide a link to the Creative Commons license and indicate if changes were made.

The images or other third party material in this chapter are included in the chapter's Creative Commons license, unless indicated otherwise in a credit line to the material. If material is not included in the chapter's Creative Commons license and your intended use is not permitted by statutory regulation or exceeds the permitted use, you will need to obtain permission directly from the copyright holder.

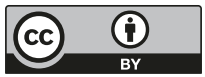

